\title{
AGE DETERMINATION OF PEARLS: A NEW APPROACH FOR PEARL TESTING AND IDENTIFICATION
}

\author{
Michael S Krzemnicki \\ Swiss Gemmological Institute SSEF, Falknerstrasse 9, 4001 Basel, Switzerland. Email: gemlab@ssef.ch. \\ Irka Hajdas \\ Laboratory of Ion Beam Physics, ETH Zurich, Schafmattstr. 20, 8093 Zurich, Switzerland. Email: hajdas@phys.ethz.ch.
}

\begin{abstract}
For this radiocarbon study, 7 saltwater pearls and 3 shells from pearl oysters have been analyzed. The declared ages of the samples range from the mid-19th century to very recent formations. The analyzed data show the potential of the bomb peak time marker to provide additional information when testing pearls. The analyzed pearls could be distinctly separated in pearls of pre- and post-bomb peak ages, in agreement with the distinction based on the declared ages. The analyzed data further reveals the potential of this method to provide supporting evidence for the historic provenience of a pearl or as an indication of a natural or cultured formation of a pearl.
\end{abstract}

\section{INTRODUCTION}

Due to their beauty, pearls have been used for adornment since prehistoric times and are among the most prized jewels, as they connote not only beauty and rarity, but also status and have thus been used as means of representation in many cultures since ancient times (Kunz 1908). Famous historic jewels and ornaments with pearls are known from the treasures of the royal courts in Europe, Russia, the Middle East, India, and China (Bennett and Mascetti 2007; Scarisbrick 2008).

With the development of pearl cultivation in the beginning of the 20th century, pearls have gained a much-increased accessibility and popularity when compared to previous ages. Now the pearl trade is a multibillion share of the worldwide jewelry market. Its products range from low-quality and inexpensive freshwater cultured pearls to rare and highly sought after natural pearls of historic provenance, such as the La Peregrina pearl (Figure 1). This natural pearl was sold in December 2011 for 11 million US dollars at auction (Christie's 2011), the highest price ever paid so far for any pearl. The price for this pearl is mostly linked to its historic provenance, being documented and depicted in paintings since the 16th century (Hans Eworth 1554, in Cooper 2008; Diego Velazquez 1634, in Lopez-Rey 1996; Finlay 2007).

Pearls are calcium carbonate $\left(\mathrm{CaCO}_{3}\right)$ concretions, formed by biomineralization by both freshwater and saltwater mollusks (Gutmannsbauer and Hänni 1994; Southgate and Lucas 2008). We can distinguish between natural pearls, which form accidentally within a mollusk, and cultured pearls that are the result of a grafting process being cultivated and harvested from a certain shell species (e.g. Pinctada maxima, Pinctada margaritifera, Pictada fucata, Unio) (Strack 2006; Müller 2009). As there is commonly a large price gap between natural pearls and cultured pearls, the trade relies on specialized gemmological laboratories to identify pearls and to distinguish natural from cultured pearls. Identification if a pearl grew as natural or cultured pearl is commonly based on radiography, $\mathrm{X}$-ray luminescence, and X-ray computed $\mu$-tomography, combined with $\mathrm{X}$-ray fluorescence (EDXRF), Raman microspectrometry, UV-Vis-NIR reflectometry and meticulous microscopic examinations (Anderson 1931; Elen 2002; Hänni 2006; Barnard and de Waal 2006; Sturman 2009; Krzemnicki et al. 2010). Recently, radiocarbon dating appeared as a new approach in pearl testing (Hänni 2008; Krzemnicki 2010; Hainschwang et al. 2010). It is the aim of this study to establish whether this method could reveal evidence for a pearl's historic provenance, and if it would distinguish between natural pearls and cultured ones.

(c) 2013 by the Arizona Board of Regents on behalf of the University of Arizona

Proceedings of the 21st International Radiocarbon Conference edited by A J T Jull \& C Hatté

RADIOCARBON, Vol 55, Nr 2-3, 2013, p 1801-1809 


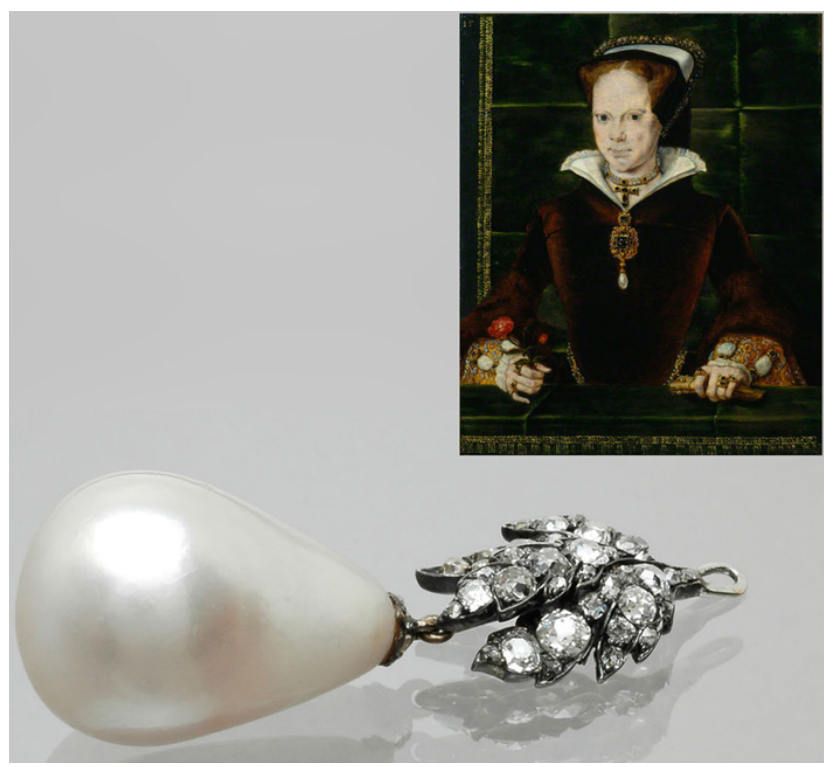

Figure 1 La Peregrina pearl, a historic natural pearl found in the 16th century and which has been depicted in several historic paintings (inset: painting by Hans Eworth ( 1520-1574) of Queen Mary I of England and Ireland, wearing a pendant with the La Peregrina pearl.

${ }^{14} \mathrm{C}$ age dating of shells has been described in numerous studies (Berger et al. 1966; Bowman and Harvey 1983; Berkman and Forman 1996; Yoneda et al. 2007). A general problem of these data is that marine reservoir ages may strongly affect the resulting ${ }^{14} \mathrm{C}$ ages of shells, especially in areas with upwelling "old" water. Although a database exists (Reimer and Reimer 2001) and is regularly extended, the correction is not always well known. Apart from this, the incorporation of e.g. limestone into the terrestrial or freshwater shell (and pearl) structure (the "hardwater effect") may further complicate the situation. These effects are especially variable for a) freshwater mollusks living in rivers and lakes and b) for gastropods grinding the soil for food (Goodfriend and Stipp 1983). For suspension-feeding saltwater mollusks (e.g. oysters) living in coastal marine habitats with known upwelling and carbon isotope ratios, analyses should result in more reliable ${ }^{14} \mathrm{C}$ ages (Taylor and Slota 1979; Rick et al. 2005). Especially for pearls and shells from pearl farms (i.e. cultivated), the habitat is well known (Brown 2005; Strack 2006; Southgate and Lucas 2008; Cartier et al. 2012). These farms are generally located in coastal regions with currents of nutrient-rich water. The oysters hang for several years in net-baskets about 3-8 m below the water surface and again about $10 \mathrm{~m}$ above sandy ground. The oysters, being filter-feeders, extract suspended organic matter (such as phytoplankton, zooplankton, and algea) and waterborne nutrients and particles (Pouvreau et al. 2000). By cleaning the shells regularly every $2-4$ weeks from attached parasites, the pearl farmers try to guarantee a constant food supply for their suspension-feeding oysters with the aim to minimize damage and thus prevent production of low-quality pearls. Natural pearls, especially from the Arabian Gulf, are originating from shells living on the shallow sandy sea ground (Carter 2000). They may accumulate into larger shell-banks, but are not directly linked to coral reefs and lagoons.

\section{PEARLING HISTORY AND RELATED PROBLEMS FOR PEARL IDENTIFICATION}

The history of pearling, shown schematically in Figure 2, can be separated into 2 very distinct periods. Until the beginning of the 20th century, there were only natural pearls found in wild shells. 
Although the first experiments to create a cultured pearl date back to the 13th century or even before, there was no successful cultured pearl production, except so-called cultured blisters, which are actually nacreous concretions accumulated directly on the inner surface of the shell on an inserted object (Sirnkiss and Wada 1980). Although early attempts by G E Streeter (Brown 2005) and William Saville-Kent (Brown and Mendis 1984) to produce cultured pearls at the end of the 19th century in Western Australia are documented, the breakthrough to create cultured pearls was actually in the beginning of the 20th century in Japan, when Tokichi Nishikawa and Tatsuhei Mise and later Kokichi Mikimoto patented their methods of pearl cultivation in 1907 and 1916, respectively. In the following years, Mikimoto started to produce cultured pearls (so-called Akoya cultured pearls) in large quantities (Strack 2006) in an unprecedented expansion. To produce these cultured pearls, he inserted a calcium carbonate bead together with a mantle tissue graft into the gonads of a mollusk from the Japanese pearl oyster (P. fucata), on which then a layer of nacre (mother-of-pearl) was forming. This process remains one of the main methods to produce saltwater cultured pearls, such as the South Sea (from P. maxima) or Tahiti cultured pearls (from P. margaritifera) (Strack 2006; Southgate and Lucas 2008). Due to the World War II, the pearl cultivation industry suffered a drawback, but regained again in the 1950s, producing large quantities of cultured pearls from $P$. fucata, while diving for natural pearls has nearly ceased. Although, already in the 1930s Japanese technicians started to experiment with the large P. maxima shells to grow larger cultured pearls, it was only in 1956 that a Japanese-Australian-American joint-venture was commercially successful in harvesting large South Sea cultured pearls at the north Australian coast (Brown 2005). In the following years, especially in the 1970s and 1980s, numerous pearl farms in Australia and French Polynesia started to supply the international trade with increasing quantities of cultured pearls, thus competing against the slowly declining Akoya cultured pearl production in Japan. Parallel to this, the 1980s and 1990s also saw the rise of the beadless freshwater cultured pearls (from Unio) in China, which in quantity have by far outnumbered the production of saltwater pearls in recent years.

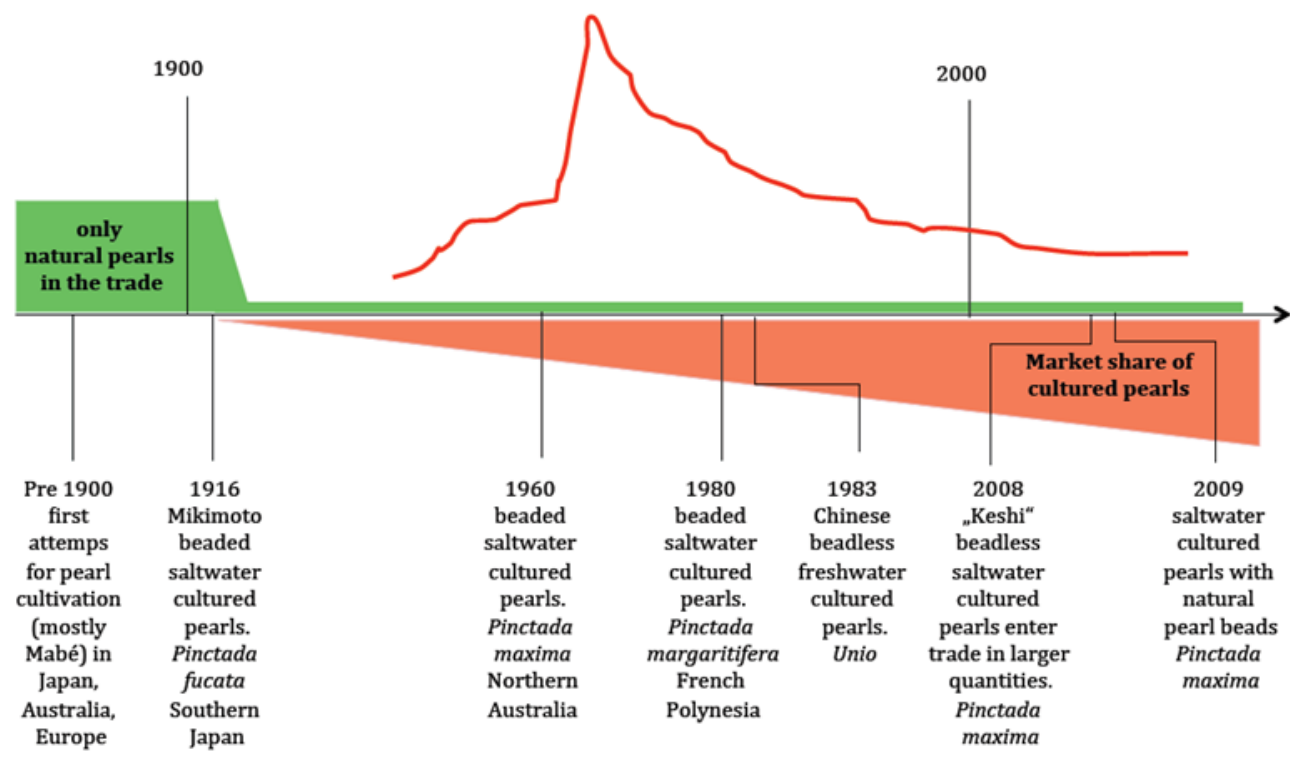

Figure 2 Scheme showing the development of the cultured pearl industry over the past $100 \mathrm{yr}$, superposed by the bomb peak (Northern Hemisphere). The market share of natural pearls has dramatically decreased with the progress of the cultured pearl industry. 


\section{S Krzemnicki \& I Hajdas}

Today, the cultured pearl industry is facing major economic challenges, partly due to the overproduction of Chinese freshwater cultured pearls. Yet, pearl farming remains an interesting craft for local communities, as it has the potential to create a sustainable development in remote coastal areas (Cartier and Ali 2012). Commercially operating pearl farms are now located in the Pacific (French Polynesia, Cook Islands, Fiji, Micronesia), Australia, Indonesia, the Philippines, Vietnam, Thailand, Myanmar, the Arabian Gulf, Sudan (Red Sea), Tanzania, and even in Baja California, Mexico (Kiefert et al. 2004; Brown 2005; Southgate et al. 2006; Strack 2006; Southgate and Lucas 2008; Müller 2009; Cartier et al. 2012).

Identification of these beaded saltwater cultured pearls is generally straightforward, as they show a distinct bead structure in radiographies. However, accidentally, this bead may be rejected or fall out of the mollusk tissue ("pearl-sac"), thus forming a cultured pearl with no bead inside. Such beadless cultured pearls may eventually show internal structures in radiographies (and X-ray $\mu$-tomography) that are very similar to the ones of natural pearls (Hänni 2006; Krzemnicki 2010; Krzemnicki et al. 2010). In recent years, such cultured pearls were even produced on purpose, partly by introducing natural pearls as beads, to mimic the appearance and structures of natural pearls, with the evident reason to deceive the buyer. This fraudulent misuse of cultured pearls has and still is considerably threatening to the natural pearl trade (Krzemnicki 2010; Hänni et al. 2010) and challenges the commercial pearl identification laboratories worldwide.

By superposing the bomb peak on the progress of the pearl industry (Figure 2), it becomes evident that ${ }^{14} \mathrm{C}$ analysis may support pearl identification. The following can be deducted assuming that the analyzed ${ }^{14} \mathrm{C}$ age is accurate (i.e. a proper reservoir age correction has been made):

- Pearls, which are distinctly older than the bomb peak (pre-20th century) are natural. The resulting age may shed light on their historic provenance. This information may be highly valuable for the antique jewelry trade.

- Pearls with a ${ }^{14} \mathrm{C}$ age younger than 1915 are either natural or cultured. But, as cultured pearls from Pinctada maxima and Pinctada margaritifera are only known since 1956, we may even assume that pearls of these mollusk species with a ${ }^{14} \mathrm{C}$ age distinctly before the bomb peak are most probably of natural origin. Pearls that are distinctly younger than the bomb peak can either be natural or cultured. However, as the recent production of cultured pearls from P. fucata, $P$. maxima, and P. maragritifera is by far exceeding the amount of newly discovered natural pearls of the same species, these young pearls are most likely cultured pearls. On the other hand, it should be stressed that, in contrast to the "old" pearls, the ${ }^{14} \mathrm{C}$ age by itself of such "young" pearls is not proof for its origin (natural or cultured) because natural pearls of the same species are formed in mollusks even at present.

\section{SAMPLE DESCRIPTION AND ANALYTICAL CONDITIONS}

For this study, we have analyzed 7 pearls and 3 shells (Table 1). Three of the pearls are saltwater natural pearls (Pinctada radiata and $P$. maxima) and 4 are saltwater cultured pearls ( $P$. maxima and $P$. fucata). The 3 shells are from $P$. radiata and P. maxima. The pearls and shells have been carefully selected a) to represent the most common pearl species known in the jewelry trade, and b) to span a range from very recent formations (harvested from pearl farms in 2009) to samples dating back presumably to the mid-19th century. As far as possible, these pearls and shells are documented, including the historic pearls donated by antique jewelry collectors and a shell (sample ETH-46326) handpicked in 2009 by one of the authors (MSK) in the Emirate Ras-al-Khaimah. Unfortunately, the precise geographic origin of some of these samples is not very well known. This is especially the case for the historic pearls, originally set in antique jewelry (ETH-46322 and -46319 shown in Figure 3, 
and ETH-46323). Based on the provided information and the analyzed properties, the authors have designated a geographic area to all of the samples to our best knowledge (Table 1).

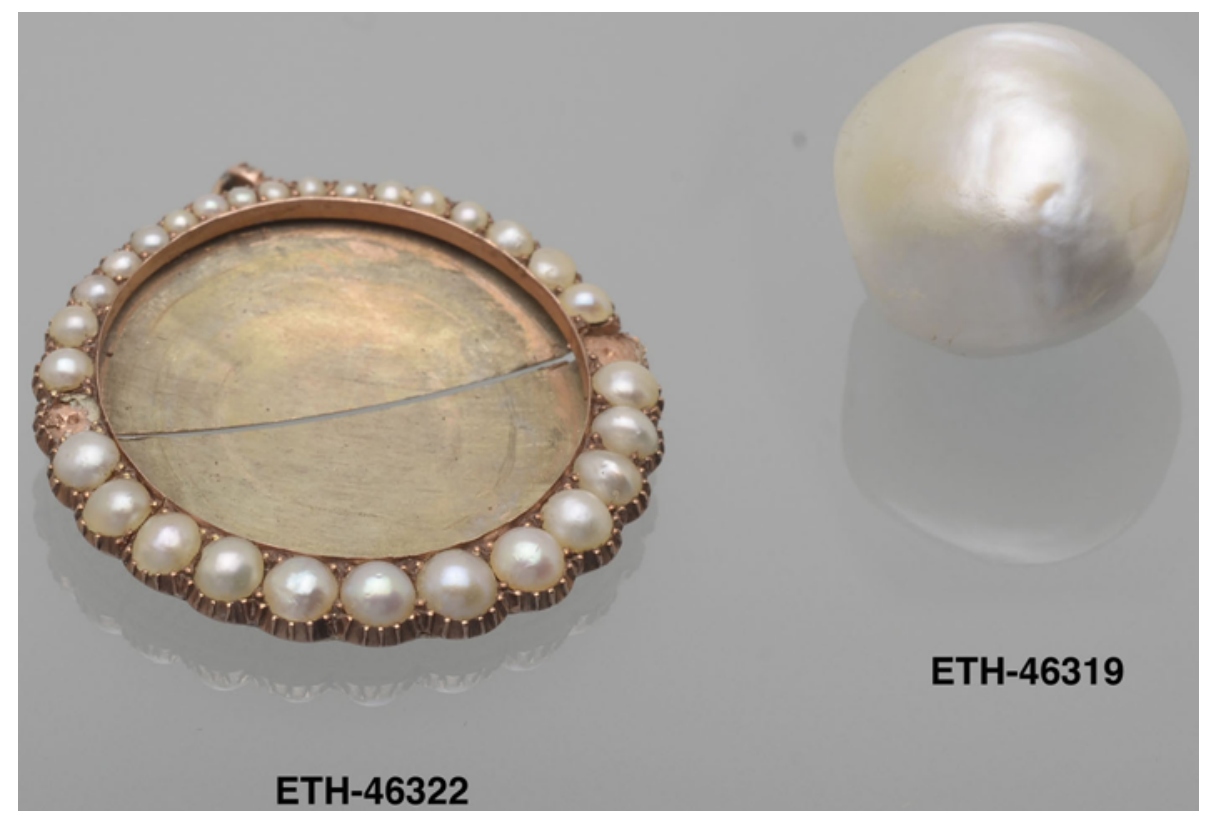

Figure 3 Two of the analyzed samples: ETH-46322, a pearl from an antique medallion-pendant with small pearls from 1860 (species Pinctada radiata from the Arabian Gulf), and sample ETH-46319, a large natural pearl (Pinctada maxima, presumably from northern Australia) with a pre-1950 age.

All the studied pearls and shells are characterized by a layer of mother-of-pearl (nacre) at the surface. The nacre consists of a densely stacked array of very tiny aragonite platelets (orthorhombic $\mathrm{CaCO}_{3}$ ), forming a robust and attractive pearly surface (Gutmannsbauer and Hänni 1994). The extraction of calcium carbonate for ${ }^{14} \mathrm{C}$ age determination was done either by abrading part of the nacre layers from the pearls or by chipping off fragments from the pearls and shells. A minimum quantity of $8 \mathrm{mg}$ was collected for each sample for the ${ }^{14} \mathrm{C}$ analyses.

Table 1 Description of material chosen for this study.

\begin{tabular}{|c|c|c|c|c|c|c|c|}
\hline Sample & Item & Formation & Origin & Species & Declared age $^{a}$ & Provenance ${ }^{\mathrm{a}}$ & Collection \\
\hline ETH-38493 & Pearl & Cultured & Saltwater & P. maxima & $\sim 2001$ & Australia/Indonesia & SSEF \\
\hline ETH-46319 & Pearl & Natural & Saltwater & P. maxima & $\sim 1940$ & Australia? & Private \\
\hline ETH-46320 & Pearl & Cultured & Saltwater & P. maxima & $\sim 2009$ & Indonesia & Private \\
\hline ETH-46321 & Pearl & Cultured & Saltwater & P. maxima & $\sim 2009$ & Indonesia & Private \\
\hline ETH-46322 & Pearl & Natural & Saltwater & P. radiata & $\sim 1860$ & Arabian Gulf & Private \\
\hline ETH-46323 & Pearl & Natural & Saltwater & P. radiata & $\sim 1880$ & Arabian Gulf & Private \\
\hline ETH-46324 & Shell & & Saltwater & P. maxima & 1990 & Philippines & SSEF \\
\hline ETH-46325 & Shell & & Saltwater & P. radiata & 1992 & Arabian Gulf & SSEF \\
\hline ETH-46326 & Shell & & Saltwater & P. radiata & 2009 & Arabian Gulf & MSK \\
\hline ETH-46327 & Pearl & Cultured & Saltwater & P. fucata & 1982 & Japan & SSEF \\
\hline
\end{tabular}

a"Declared" age and the provenance are indicated to our best knowledge based on the provided information. 


\section{S Krzemnicki \& I Hajdas}

\section{Sample Treatment and Preparation}

Pieces of pearls were subject to washing in ultrapure water. On average, $8 \mathrm{mg}$ of pearl material was placed in gas bench tubes and flushed with helium flow, then dissolved in concentrated phosphoric acid (85\%) and transferred to the graphitization system (Wacker et al. 2013). Graphite was then pressed into targets (cathodes) and the ${ }^{14} \mathrm{C} /{ }^{12} \mathrm{C}$ ratio was measured using the MICADAS system (Synal et al. 2007).

\section{RESULTS AND DISCUSSION}

After correction for blank values and fractionation $\left(\delta^{13} \mathrm{C}\right)$, the measured ${ }^{14} \mathrm{C} /{ }^{12} \mathrm{C}$ concentration was used to calculate conventional ${ }^{14} \mathrm{C}$ ages (Stuiver and Polach 1977). For all samples, the calculated ${ }^{14} \mathrm{C}$ age $\mathrm{BP}$ was corrected using the following approach: reservoir correction was assigned to each location using the database of marine reservoir correction (Reimer and Reimer 2001 and references therein). These were estimated (weighted mean) based on 10 data points in the vicinity of the sampling site. The corrected ${ }^{14} \mathrm{C}$ ages were then calibrated using IntCal09 data (Reimer et al. 2009) and SHCal04 (McCormac et al. 2004). The marine data set of IntCal09 was used in the case of 2 historical samples from the Northern Hemisphere ( $\mathrm{NH}$; see Table 2). If corrected ${ }^{14} \mathrm{C}$ ages were negative, their calendar ages were estimated using bomb peak data for the corresponding regions $\mathrm{NH}$ (Levin and Kromer 2004; Levin et al. 2008) and Southern Hemisphere (SH; Hua and Barbetti 2004) using OxCal v 4.1.7 (Bronk Ramsey 2009) or CALIBomb (http://calib.qub.ac.uk/CALIBomb/ frameset.html) using $\mathrm{F}^{14} \mathrm{C}$ (Reimer et al. 2004) calculated after correction for reservoir ages. Comparing the corrected ${ }^{14} \mathrm{C}$ ages with the "declared" age of the samples (Table 2), one can observe that the samples formed after the bomb peak can be well separated from the ones with "declared" historic ages (ETH-46322, ETH-46323, and ETH-46319).

Table 2 Results of ${ }^{14} \mathrm{C}$ analysis: ${ }^{14} \mathrm{C}$ ages were corrected for reservoir age estimated for the locations (average of 10 data points near location of the sampling site), calibrated using corresponding data set. For samples with negative corrected ${ }^{14} \mathrm{C}$ ages, the corrected $\mathrm{F}^{14} \mathrm{C}$ value was calculated.

\begin{tabular}{|c|c|c|c|c|c|c|c|c|c|}
\hline $\begin{array}{l}\text { Lab code } \\
\text { (ETH-) }\end{array}$ & Item & $\begin{array}{l}\text { Declared } \\
\text { age }^{\mathrm{a}}\end{array}$ & $\begin{array}{l}{ }^{14} \mathrm{C} \text { age } \\
\mathrm{BP}(1 \sigma)\end{array}$ & $\begin{array}{l}\delta^{13} \mathrm{C} \\
(\%)\end{array}$ & $\begin{array}{l}\text { Res. } \\
\text { age }\end{array}$ & $\begin{array}{l}\text { Corr. }{ }^{14} \mathrm{C} \\
\text { age (BP) }\end{array}$ & $\begin{array}{l}\text { Corrected } \\
\mathrm{F}^{14} \mathrm{C}\end{array}$ & $\begin{array}{l}\text { Calendar } \\
\text { age AD }\end{array}$ & $\begin{array}{l}\text { Calibration } \\
\text { data set }\end{array}$ \\
\hline 38493 & Pearl & $\sim 2001$ & $-455 \pm 30$ & -5.4 & 467 & $-922 \pm 27$ & $\begin{array}{l}1.1216 \pm \\
0.0038\end{array}$ & $\begin{array}{l}1958-1959, \\
1994-1996\end{array}$ & CALIBomb: SH1 \\
\hline 46319 & Pearl & pre-1950 & $765 \pm 30$ & 3.0 & 467 & $298 \pm 27$ & & $1623-1781$ & SHCal04 \\
\hline 46320 & Pearl & $\sim 2009$ & $-290 \pm 25$ & 0.1 & 466 & $-756 \pm 26$ & $\begin{array}{l}1.0987 \pm \\
0.0036\end{array}$ & 1958 & CALIBomb: SH1 \\
\hline 46321 & Pearl & $\sim 2009$ & $-290 \pm 25$ & -1.5 & 466 & $-756 \pm 26$ & $\begin{array}{l}1.0987 \pm \\
0.0036\end{array}$ & 1958 & CALIBomb: SH1 \\
\hline 46322 & Pearl & $\sim 1860$ & $730 \pm 30$ & 0.6 & 595 & $135 \pm 54$ & & $1600-1950$ & Marine IntCal09 \\
\hline 46323 & Pearl & $\sim 1880$ & $610 \pm 30$ & 0.5 & 595 & $15 \pm 54$ & & $1708-1950$ & Marine IntCal09 \\
\hline 46324 & Shell & 1990 & $-805 \pm 25$ & 0.1 & 453 & $-1258 \pm 41$ & $\begin{array}{l}1.1695 \pm \\
0.0060\end{array}$ & $\begin{array}{l}\text { 1959-1960, } \\
1988-1992\end{array}$ & CALIBomb: SH1 \\
\hline 46325 & Shell & 1992 & $-965 \pm 25$ & -0.2 & 595 & $-1560 \pm 53$ & $\begin{array}{l}1.2143 \pm \\
0.0080\end{array}$ & $\begin{array}{l}1958-1961, \\
1983-1985\end{array}$ & CALIBomb: Levin \\
\hline 46326 & Shell & 2009 & $-155 \pm 25$ & -2.0 & 595 & $-750 \pm 53$ & $\begin{array}{l}1.0979 \pm \\
0.0072\end{array}$ & $\begin{array}{l}\text { 1954-1958, } \\
1995-2001\end{array}$ & CALIBomb: Levin \\
\hline 46327 & Pearl & 1982 & $485 \pm 30$ & -0.6 & 508 & $-23 \pm 46$ & $\begin{array}{l}1.0029 \pm \\
0.0058\end{array}$ & $1950-2008$ & CALIBomb: Levin \\
\hline
\end{tabular}

a"Declared" age and the provenance are indicated to our best knowledge based on the provided information.

The oldest sample (ETH-46322), a natural pearl originally set in an antique medallion-pendant (Figure 3) dated to about 1860 , shows a rather matching corrected ${ }^{14} \mathrm{C}$ age (Figure 4). Also, the sample ETH-46323 set in an antique brooch reveals an age that falls into the problematic time of the cali- 
bration curve where multiple intervals correspond to the measured ${ }^{14} \mathrm{C}$ age. Nevertheless, the "declared" age of AD 1880 is well within the possible calendar ages.

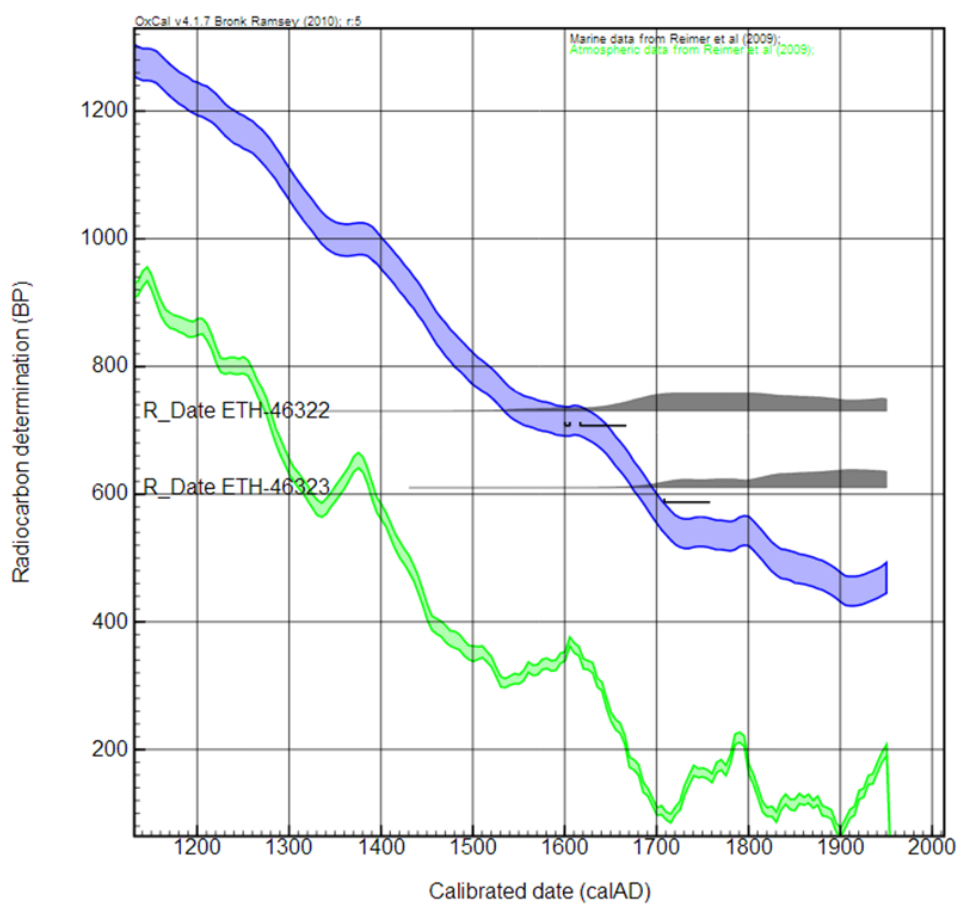

Figure 4 Calibrated of ages of 2 historic pearls (ETH-46322 and -46323) that were formed before the bomb peak. Both pearls originate from the Arabian Gulf and were calibrated using the marine calibration curve IntCal09 (Reimer et al. 2009) and $\Delta \mathrm{R}=190 \pm 180 \mathrm{yr}$.

Sample ETH-46319, a large pearl of Pinctada maxima (Figure 3), although declared as being pre1950 , reveals a historic age of AD 1623-1781 ( $2 \sigma$ probability). From the information provided by the collector, the measured ${ }^{14} \mathrm{C}$ age is possible, but unfortunately historic age is not well documented. However, despite the unknown accuracy of the historic age, the age provided by the ${ }^{14} \mathrm{C}$ age determination allows in this specific case to unambiguously identify the sample as a natural pearl. This was not possible when only previous testing with radiography and X-ray computed $\mu$-tomography was applied because these methods gave inconclusive results. The fact that cultured $P$. maxima pearls of such large size were only produced commercially after the bomb peak and the prebomb ${ }^{14} \mathrm{C}$ age helped to resolve the problem. For the 7 more recent pearls and shell samples, which formed distinctly after the bomb-peak, the calculated and corrected ${ }^{14} \mathrm{C}$ ages in 4 cases quite well match their "declared" ages (ETH-46324, -46325, -38493, -46326), whereas the cultured pearl from Japan (ETH-46327) with a declared age of 1982 and the 2 cultured pearls from Indonesia (ETH$46320,-46321)$ from 2009 reveal older ages. This again might indicate some variability in reservoir ages of this region that affects our results. Nevertheless, the results of our study show that pearls detect bomb ${ }^{14} \mathrm{C}$, which proves the potential of ${ }^{14} \mathrm{C}$ in pearls for detection of this time marker.

\section{CONCLUSIONS}

This study has shown that ${ }^{14} \mathrm{C}$ age determination can provide additional valuable information when testing pearls. We can distinguish 2 very different scopes. In the case of antique jewelry and trea- 


\section{S Krzemnicki \& I Hajdas}

sures, age determination may support evidence for their historic provenance (e.g. sample ETH46322). This can be very important, especially in the case of pearls of iconic significance in cultural history. A pearl set in a historic jewelry item revealing a recent age (after the bomb peak) would indicate that the item had been manufactured, likely with fraudulent intention. In the case of more recent ages close to the bomb peak, ${ }^{14} \mathrm{C}$ age dating might be supporting evidence that enables us to conclude whether a pearl is a natural or cultured formation. This is based on the fact that the methods to cultivate pearls from certain mollusk species (Pinctada maxima, Pinctada margaritifera) have been developed at or distinctly after the bomb peak (Figure 2 ). Thus, a ${ }^{14} \mathrm{C}$ age of such a pearl species close to the bomb peak nearly rules out a formation as a cultured pearl (e.g. ETH-46319). However, it has to be stressed that such assumptions only can be drawn after careful identification of the mollusk species of the pearl. For pearls that show very young ages, this method is only of limited use, as it cannot distinguish between a young natural pearl or a cultured pearl. In such cases, pearl identification has to rely mostly on radiography and X-ray computed $\mu$-tomography.

\section{ACKNOWLEDGMENTS}

The authors would like to thank the following persons for donations and loans: Thomas Faerber (Faerber Collection, Geneva), José Casares (Shanghai Gems, Geneva), Henry A. Hänni (GemExpert, Basel), Jeremy Norris (Oasis Pearl, Albion CA, USA), Imura Daiji and Abdulla Rashed AlSuwaidi (RAK Pearls, Ras-Al-Khaimah, UAE). Special thanks to Georges Bonani (LIP, ETH Zurich), who pioneered this work together with Henry A Hänni (GemExpert, Basel). Many thanks to Mantana Maurer, Carol Biechele, Martin Seiler, and Lukas Wacker (LIP ETH Zurich) for their support with sample preparation and AMS analysis.

\section{REFERENCES}

Anderson BW. 1931. The use of X rays in the study of pearls. British Journal of Radiology 5:57-64.

Barnard W, de Waal D. 2006. Raman investigation of pigmentary molecules in the molluscan biogenic matrix. Journal of Raman Spectroscopy 36(1-3):342-52.

Bennett D, Mascetti D. 2007. Understanding Jewellery. Woodbridge: Antique Collectors Club. 3rd edition. $496 \mathrm{p}$.

Berger R, Taylor RE, Libby WF. 1966. Radiocarbon content of marine shells form the California and Mexican west coast. Science 153(3738):864-6.

Berkman PA, Forman SL. 1996. Pre-bomb radiocarbon and the reservoir correction for calcareous marine species in the Southern Ocean. Geophysical Research Letters 23(4):363-6.

Bowman GM, Harvey N. 1983. Radiocarbon dating marine shells in South Australia. Australian Archaeology 17:113-23.

Bronk Ramsey C. 2009. Bayesian analysis of radiocarbon dates. Radiocarbon 51(1):337-60.

Brown G. 2005. The Australian Pearling Industry and Its Pearls. The Gemmological Association of Australia. http://www.gem.org.au/pearl.htm. Accessed 2012.

Brown G, Mendis H. 1984. An unusual cultured pearl necklace. Australian Gemmologist 15(5):155-7.

Carter R. 2000. The history and prehistory of pearling in the Persian Gulf. Journal of the Economic and Social History of the Orient 48(2):139-209.

Cartier LE, Ali SH. 2012. Pearl farming as a sustainable development path. The Solutions Journal 4(3):30-4. http://www.thesolutionsjournal.com/node/1139. Accessed 18 October 2012.

Cartier LE, Krzemnicki MS, Ito M. 2012. Cultured pearl farming and production in the Federated States of Micronesia. Gems \& Gemology 48(2):108-22.

Christie's. 2011. Auction catalogue. http:// www.christies.com/lotfinder/jewelry/la-peregrina-anatural-pearl-diamond-5507887-details.aspx. Accessed 18 October 2012.

Cooper T. 2008. A Guide to Tudor \& Jacobean Portraits. London: National Portrait Gallery Publications. 48 p.

Elen S. 2002. Identification of yellow cultured pearls from the black-lipped oyster Pinctada margaritifera. Gems \& Gemology 38(1):66-72.

Finlay V. 2007. Jewels: A Secret History. New York: Random House Publishing Group. 496 p.

Goodfriend GA, Stipp JJ. 1983. Limestone and the problem of radiocarbon dating of land-snail shell carbonate. Geology 11(10):575-7.

Gutmannsbauer W, Hänni HA. 1994. Structural and chemical investigations on shells and pearls of nacre forming salt- and freshwater bivalve molluses. Journal of Gemmology 24(4):241-52.

Hainschwang T, Hochstrasser T, Hajdas I, Keutschegger W. 2010. A cautionary tale about a little-known type of non-nacreous calcareous concretion produced by the Magilus antiquus marine snail. Journal of Gemmology 32(1/4):15-22. 


\section{New Approach for Pearl Testing and Identification}

Hänni HA. 2006. A short review of the use of 'keshi' as a term to describe pearls. Journal of Gemmology 30(1/ 2):52-8.

Hänni HA. 2008. Radiocarbon dating of "Neptunian" beads from Asia proves modern origin. Gems \& Gemology 44(4):376-7.

Hänni HA, Krzemnicki MS, Cartier L. 2010. Appearance of new bead material in cultured pearls. Journal of Gemmology 32(1/4):31-7.

Hua Q, Barbetti M. 2004. Review of tropospheric bomb ${ }^{14} \mathrm{C}$ data for carbon cycle modeling and age calibration purposes. Radiocarbon 46(3):1273-98.

Kiefert L, Moreno DM, Arizmendi E, Hänni HA, Elen S. 2004. Cultured pearls from the Gulf of California, Mexico. Gems \& Gemology 40(1):26-38.

Krzemnicki MS. 2010. "Keshi” cultured pearls are entering the natural pearl trade. SSEF Trade Alert. May 2010. URL: http://www.ssef.ch/research-publications/press-releases/. Accessed October 2012.

Krzemnicki MS, Friess S, Chalus P, Hajdas I, Hänni HA. 2009. New developments in pearl analysis: X-ray micro tomography and radiocarbon age dating. Journal of the Gemmological Association of Hong Kong 30: 43-5.

Krzemnicki MS, Friess SD, Chalus P, Hänni HA, Karampelas S. 2010. X-ray computed microtomography: distinguishing natural pearls from beaded and non-beaded cultured pearls. Gems \& Gemology 46(2):128-34.

Kunz GF. 1908. The Book of the Pearl; The History, Art, Science, and Industry of the Queen of Gems. New York: The Century Co. Publishers. $548 \mathrm{p}$.

Levin I, Kromer B. 2004. The tropospheric ${ }^{14} \mathrm{CO}_{2}$ level in mid-latitudes of the Northern Hemisphere (19592003). Radiocarbon 46(3):1261-72.

Levin I, Hammer S, Kromer B, Meinhardt F. 2008. Radiocarbon observations in atmospheric $\mathrm{CO}_{2}$ : determining fossil fuel $\mathrm{CO}_{2}$ over Europe using Jungfraujoch observations as background. Science of The Total Environment 391(2-3):211-6.

Lopez-Rey J. 1996. Velazquez. Maler der Maler. Sämtliche Werke. Catalogue raisonné. Cologne: Taschen. $264 \mathrm{p}$.

McCormac FG, Hogg AG, Blackwell PG, Buck CE, Higham TFG, Reimer PJ. 2004. SHCal04 Southern Hemisphere calibration, 0-11.0 cal kyr BP. Radiocarbon 46(3): 1087-92.

Müller A. 2009. A brief analysis of the global seawater cultured pearl industry (past, present, future). Presentation at the 3rd European Gemmological Symposium in June 2009, Bern, Switzerland.

Pouvreau S, Bodoy A, Buestel D. 2000. In situ suspension feeding behaviour of the pearl oyster, Pinctada margaritifera: combined effects of body size and weather-related seston composition. Aquaculture 181(1-2):91-113.

Reimer P, Brown T, Reimer R. 2004. Discussion: reporting and calibration of post-bomb ${ }^{14} \mathrm{C}$ data. Radiocar- bon 46(3):1299-304.

Reimer PJ, Baillie MGL, Bard E, Bayliss A, Beck JW, Blackwell PG, Bronk Ramsey C, Buck CE, Burr GS, Edwards RL, Friedrich M, Grootes PM, Guilderson TP, Hajdas I, Heaton T, Hogg AG, Hughen KA, Kaiser KF, Kromer B, McCormac FG, Manning SW, Reimer RW, Richards DA, Southon JR, Talamo S, Turney CSM, van der Plicht J, Weyhenmeyer CE. 2009. IntCal09 and Marine09 radiocarbon age calibration curves, 0-50,000 years cal BP. Radiocarbon 51(4): 1111-50.

Reimer PJ, Reimer RW. 2001. A marine reservoir correction database and on-line interface. Radiocarbon 43(2A): 461-3.

Rick TC, Vellanoweth RL, Erlandson JM. 2005. Radiocarbon dating and the "old shell" problem: direct dating of artifacts and cultural chronologies in coastal and other aquatic regions. Journal of Archaeological Science 32(11):1641-8.

Scarisbrick D. 2008. Brilliant Europe: Jewels from European Courts. Mercator Fonds Publishers. $296 \mathrm{p}$

Sirnkiss K, Wada K. 1980. Cultured pearls - commercialised biomineralisation. Endeavor, New Series 4(1): $32-7$.

Southgate PC, Lucas JS. 2008. The Pearl Oyster. Oxford: Elsevier.

Southgate P, Rubens J, Kipanga M, Msumi G. 2006. Pearls from Africa. SPC Pearl Oyster Information Bulletin 17:16-7.

Strack E. 2006. Pearls. Stuttgart: Rühle-Diebener Verlag. $707 \mathrm{p}$.

Stuiver M, Polach HA. 1977. Discussion: reporting of ${ }^{14} \mathrm{C}$ data. Radiocarbon 19(3):355-63.

Sturman N. 2009. The microradiographic structures of nonbead cultured pearls, August 20th 2009. GIA Lab Notes. URL: http://www.giathai.net/pdf/ The_Microradiographic_structures_in_NBCP.pdf. Accessed 9 October 2012.

Synal H-A, Stocker M, Suter M. 2007. MICADAS: a new compact radiocarbon AMS system. Nuclear Instruments and Methods in Physics Research B 259(1): $7-13$.

Taylor RE, Slota PJ. 1979. Fraction studies on marine shell and bone samples for radiocarbon analyses. In: Berger R, Suess HE, editors. Radiocarbon Dating. Berkeley: University of California Press. p 422-32.

Wacker L, Fulop R, Hajdas I, Molnar M, Rethemeyer J. 2013. A novel approach to process carbonate samples for radiocarbon measurements with helium carrier gas. Nuclear Instruments and Methods in Physics Research B 294:214-7.

Yoneda M, Uno H, Shibata Y, Suzuki R, Kumamoto Y, Yoshida K, Sasaki T, Suzuki A, Kawahata H. 2007. Radiocarbon marine reservoir ages in the western Pacific estimated by pre-bomb molluscan shells. Nuclear Instruments and Methods in Physics Research B 259(1): $432-7$. 